\title{
GENETIC STUDIES ON WILD POPULATIONS OF MELANDRIUM
}

\section{FLOWERING TIME AND PLANT WEIGHT}

\author{
C. W. LAWRENCE
}

Genetics Department, Birmingham University *

Received 27.viii.62

\section{INTRODUCTION}

MANY studies have shown that there is often considerable heritable variation to be found in wild species (see Stebbins, 1950). Much of this variation is of a quantitative, rather than a qualitative, nature which suggests that the genetic variation between wild populations is largely polygenic (Mather, I953). Few studies, however, have analysed the variation in any detail. In the following account, quantitative variation between samples from four populations of Melandrium album and two of $M$. rubrum has been examined and its inheritance studied in a set of diallel crosses. The genetic activity of the sex chromosomes has also been examined in these dioecious species particularly in relation to differences arising between male and female plants.

\section{MATERIAL AND METHOD}

The locations of the populations studies are given in table $\mathrm{r}$. Samples of seed were collected from ten randomly chosen plants at each location. The seed from any one location was mixed and from the resulting plants three males and three females were taken at random to be used in the crossing programme. Males and

TABLE I

Location of material

\begin{tabular}{|c|c|c|}
\hline Sample & Habitat & Location \\
\hline $\begin{array}{l}W_{1} \\
W_{5} \\
W_{7} \\
W_{8} \\
R_{4} \\
R_{5}\end{array}$ & $\begin{array}{l}\text { Cultivated field } \\
\text { Hedgerow } \\
\text { Uncultivated field } \\
\text { Cultivated field } \\
\text { Hedgerow } \\
\text { Hedgerow }\end{array}$ & $\begin{array}{l}\text { Bayford, Herts } \\
\text { Essendon, Herts } \\
\text { Hertford, Herts } \\
\text { Whitacre, Warwicks } \\
\text { Whitacre, Warwicks } \\
\text { Aberystwyth, Cards }\end{array}$ \\
\hline
\end{tabular}

$\mathrm{W}=M$. album. $\mathrm{R}=M$. rubrum.

females from the same sample were crossed together in all possible ways, and those from different samples in six random but independent pairs, using each male and female once only. A total of $(6 \times 9)+(15 \times 6)=144$ crosses was therefore made. Each pollination was carried out with an excess of pollen. Two randomised plots

- Present address : Wantage Research Laboratory (A.E.R.E.), Wantage, Berks. K 2 
of ten plants from each cross were planted in one block. Since a number of crosses gave poor or delayed germination, the data from duplicate plots was pooled.

Three metrics were taken from the plants :-

(i) Flowering time; the number of days from an arbitrary date to the opening of the first flower.

(ii) Plant weight; the wet weight in ounces.

(iii) The proportion of females in the progeny.

1918 plants were examined.

\section{RESULTS}

The data were first examined by means of analyses of the variance within and between groups of intra- and inter- population crosses, male and female progeny being treated separately. The sex differences, expressed as the mean difference between males and females within a single plot, was also analysed in this way. The methods of Jinks (r954) and Hayman (r958) for the analysis of diallel tables were then employed. As before (Lawrence, r 1963) the groups of intra- and inter-population crosses are called "parents" and " $F_{1}$ 's" respectively.

\section{(i) Flowering time}

The average flowering time of the different groups of male and female progeny are given in table 2, and the corresponding results

TABLE 2

The average flowering time for each parent and $F_{1}$ group

\begin{tabular}{|c|c|c|c|c|c|c|}
\hline & $W_{I}$ & $\mathrm{~W}_{5}$ & $w_{7}$ & w8 & $\mathrm{R}_{4}$ & $\mathrm{R}_{5}$ \\
\hline$W_{I}$ & $\begin{array}{l}36 \cdot 5 \\
26 \cdot 2\end{array}$ & $\begin{array}{l}34 \cdot 2 \\
24 \cdot 2\end{array}$ & $\begin{array}{l}26 \cdot 8 \\
23 \cdot 0\end{array}$ & $\begin{array}{l}21 \cdot 7 \\
24 \cdot 1\end{array}$ & $\begin{array}{l}27 \cdot 9 \\
27 \cdot 0\end{array}$ & $\begin{array}{l}23 \cdot 3 \\
25 \cdot 6\end{array}$ \\
\hline $\mathrm{w}_{5}$ & $\begin{array}{l}37 \cdot 8 \\
28 \cdot 8\end{array}$ & $\begin{array}{l}46 \cdot 7 \\
29 \cdot 8\end{array}$ & $\begin{array}{l}32 \cdot 1 \\
26 \cdot 9\end{array}$ & $\begin{array}{l}3 \mathrm{I} \cdot 8 \\
25 \cdot 4\end{array}$ & $\begin{array}{l}29 \cdot 5 \\
24 \cdot 0\end{array}$ & $\begin{array}{l}26 \cdot 6 \\
23 \cdot 3\end{array}$ \\
\hline $\mathrm{w}_{7}$ & $\begin{array}{l}32 \cdot 4 \\
30 \cdot 8\end{array}$ & $\begin{array}{l}4 \mathrm{I} \cdot 5 \\
35 \cdot 5\end{array}$ & $\begin{array}{l}3 I \cdot 8 \\
27 \cdot 4\end{array}$ & $\begin{array}{l}29 \cdot 3 \\
25 \cdot 2\end{array}$ & $\begin{array}{l}3 \mathrm{I} \cdot 9 \\
33 \cdot 7\end{array}$ & $\begin{array}{l}24 \cdot I \\
26 \cdot 4\end{array}$ \\
\hline W8 & $\begin{array}{l}32 \cdot 5 \\
28 \cdot 2\end{array}$ & $\begin{array}{l}47 \cdot 0 \\
30 \cdot 4\end{array}$ & $\begin{array}{l}28 \cdot 3 \\
22.5\end{array}$ & $\begin{array}{l}34.0 \\
33.5\end{array}$ & $\begin{array}{l}32 \cdot 5 \\
45 \cdot 6\end{array}$ & $\begin{array}{l}31 \cdot 8 \\
29 \cdot 6\end{array}$ \\
\hline $\mathrm{R}_{4}$ & $\begin{array}{l}42 \cdot 3 \\
38 \cdot 6\end{array}$ & $\begin{array}{l}37 \cdot \mathbf{0} \\
33 \cdot \mathbf{I}\end{array}$ & $\begin{array}{l}33 \cdot 1 \\
29 \cdot 7\end{array}$ & $\begin{array}{l}22 \cdot 4 \\
30 \cdot 4\end{array}$ & $\begin{array}{l}35^{\circ} 8 \\
37^{\circ} \mathrm{o}\end{array}$ & $\begin{array}{l}25.8 \\
32.8\end{array}$ \\
\hline $\mathrm{R}_{5}$ & $\begin{array}{l}31 \cdot 3 \\
29 \cdot 1\end{array}$ & $\begin{array}{l}36 \cdot 2 \\
27 \cdot 9\end{array}$ & $\begin{array}{l}23 \cdot 8 \\
22 \cdot 0\end{array}$ & $\begin{array}{l}3 \mathrm{I} \cdot 9 \\
3 \mathrm{O} \cdot \mathrm{I}\end{array}$ & $\begin{array}{l}37.5 \\
43 \cdot 2\end{array}$ & $\begin{array}{l}30 \cdot 5 \\
3^{2} \cdot 9\end{array}$ \\
\hline
\end{tabular}

Top figure $=$ female plants. $\quad$ Bottom figure $=$ male plants 
of analyses of variance in table 3 . It can be seen that in both sexes there is considerably more variation between groups than within them, and that these differences are significant (table 3 , item $\mathrm{I}$ ). Table 2 shows that the action of at least several, and probably many, genes is indicated by the variation.

Despite this superficial similarity in the analyses of males and females, a great difference between them is revealed when the distribution of the variation is examined in detail. In the females there is highly significant variation among both parents and $\mathrm{F}_{1}$ 's (table 3, items $I$ (i) and (ii) and also a consistent deviation of the $F_{1}$ 's from the mid parent (item I (iii)). The significance of these items shows that there is both additive and dominance variation between the samples in female flowering time. None of these items is significant in the males, but unlike the females there are highly significant differences between the groups of reciprocal crosses (item I (iv)). This contrast between the sexes shows that much, and possibly all, of the variation in flowering time in these samples resides in the sex chromosomes. The absence of consistent paternal inheritance in male progeny suggests that only the $\mathrm{X}$ chromosome is active.

$\mathrm{Wr} / \mathrm{Vr}$ (Jinks, I954; Dickinson and Jinks, 1956) and W'r/Vr (Hayman, I 958) graphs of male and female flowering time are shown in fig. I. The presence of sex chromosome activity does not disturb the expectations for these graphs in either sex if $F_{1}$ values are obtained by pooling reciprocal data (Jinks unpub.).

For female data both the $\mathrm{Wr} / \mathrm{Vr}$ and $\mathrm{W}^{\prime} \mathrm{r} / \mathrm{Wr}$ regressions are significant $(\mathrm{P}=0.0 \mathrm{I}-0.00 \mathrm{I}$ in both cases), indicating that the samples differ in their properties of dominance. $\mathrm{R}_{4}$ and $\mathrm{R}_{5}$ have the greatest number of dominant alleles among these samples, or possibly the dominant alleles of greatest effect. $\mathrm{W}_{5}, \mathrm{~W}_{7}$ and $\mathrm{W} 8$ have the greatest number of recessive alleles, and $W_{I}$ is intermediate between the two groups. The relatively greater scatter of points about the $\mathrm{Wr} / \mathrm{Vr}$, compared with the $\mathrm{W}^{\prime} \mathrm{r} / \mathrm{Wr}$, regression probably arises from heterozygosity. Differences in the level of heterozygosity among the various samples lead to an arrangement of the points on parallel lines of unit slope on the $\mathrm{Wr} / \mathrm{Vr}$, but not the $\mathrm{W}^{\prime} \mathrm{r} / \mathrm{Wr}$, graph (Dickinson and Jinks, 1956). The significance of these differences cannot however be tested in the present data, and greater scatter about the $\mathrm{Wr} / \mathrm{Vr}$ regression may also in part arise from purely statistical considerations. In the presence of heterozygosity the slope of the $\mathrm{Wr} / \mathrm{Vr}$ regression does not have a precise expectation (Dickinson and Jinks, loc. cit.) but the observed slope of $+0.840 \pm 0.258$ is close to the approximate value of +0.9 which is expected in the absence of non-allelic interaction. The slope of the $\mathrm{W}^{\prime} \mathrm{r} / \mathrm{Wr}$ regression $(b=+0.580 \pm 0.074)$ does not deviate significantly from the expected +0.5 (Hayman, 1958).

The contrast between male and female data in the analyses of variance is maintained in the $\mathrm{Wr} / \mathrm{Vr}$ and $\mathrm{W}^{\prime} \mathrm{r} / \mathrm{Wr}$ analyses. The $\mathrm{Wr} / \mathrm{Vr}$ regression for male flowering time is not significant, but 


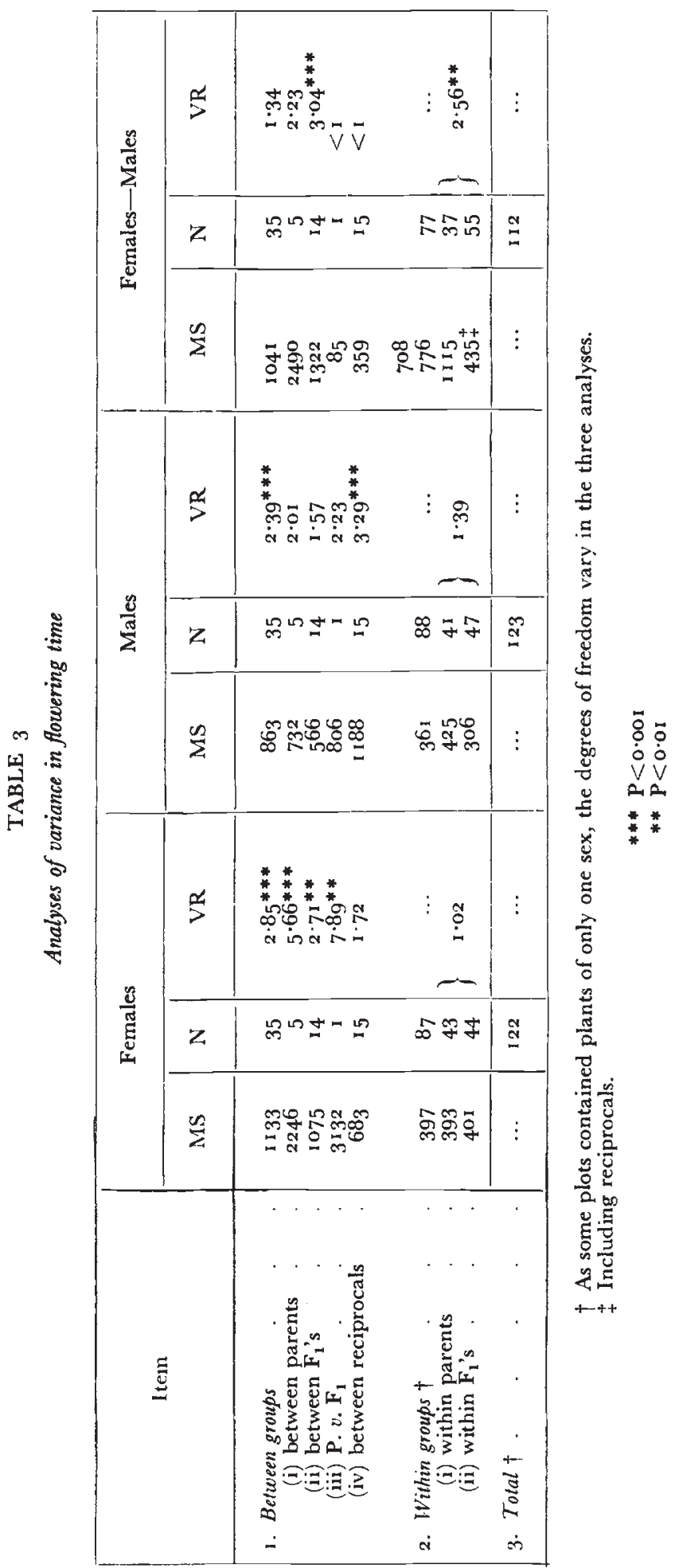


unexpectedly there is a significant $\left(\mathrm{P}=0.05^{-0} \cdot 0 \mathrm{I}\right)$ linear relation between $W^{\prime} r$ and $\mathrm{Wr}$. This presumably arises from a small autosomal activity or activity of the pairing segment of the sex chromosomes which

Flowering Time $\sigma^{\circ} \sigma^{\circ}$

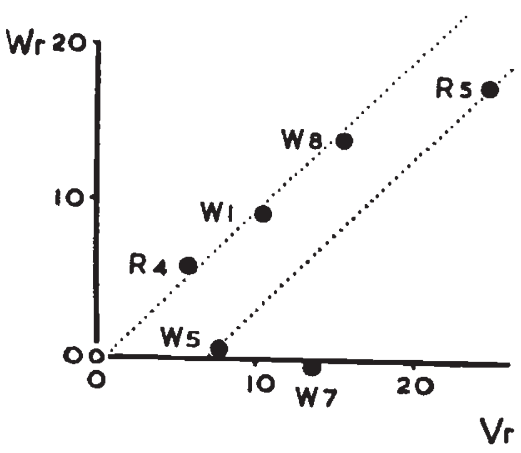

$D=+0.359 \pm 0.157$

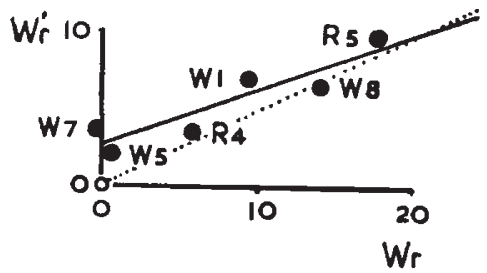

qq

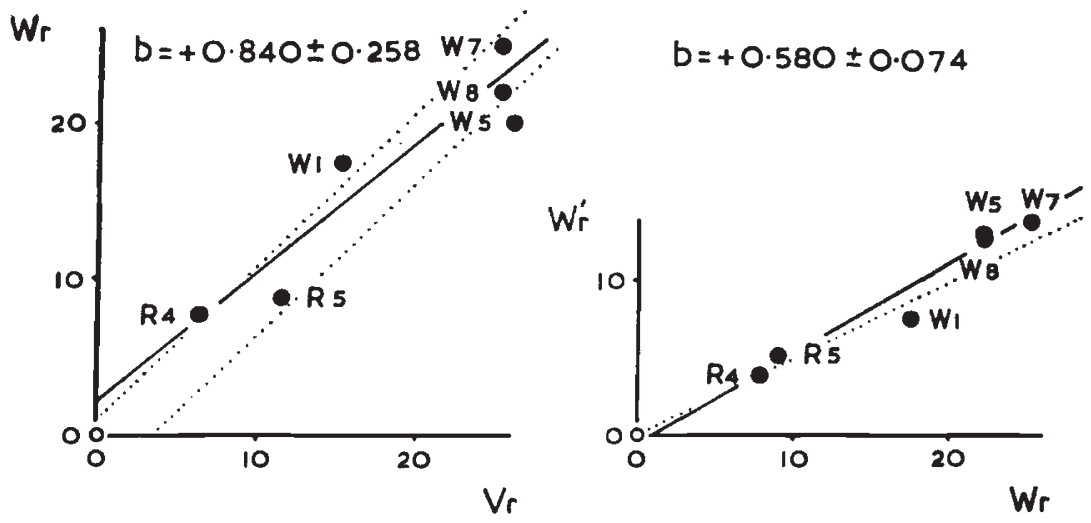

Fug. 1.- $\mathrm{Wr} / \mathrm{Vr}$ and $\mathrm{W}^{\prime} \mathrm{r} / \mathrm{Wr}$ graphs for male and female flowering time. Broken lincs on the $\mathrm{Wr} / \mathrm{Vr}$ graphs have unit slope and have been fitted to the data by eye. Broken lines in the $W^{\prime} r / W r$ graphs have a slope of +0.5 and pass through the origin.

was not detected by the analysis of variance. In this case the insignificance of the $\mathrm{Wr} / \mathrm{Vr}$ regression arises from heterozygosity and/or nonallelic interaction. Heterozygosity is suggested by the distribution of five of the points on two parallel lines of unit slope. The difference between the sexes is further emphasised by the dominance ranking of the samples. Among the males $\mathrm{W}_{7}$ and $\mathrm{W}_{5}$ are the most dominant, $\mathrm{W}_{\mathrm{I}}$ and $\mathrm{R}_{4}$ are intermediate, and $\mathrm{R}_{5}$ and $\mathrm{W} 8$ the most recessive. This order is quite different from that in the females. Since a few crosses gave progeny of only one sex, the results of the analyses are 
not strictly comparable. It is, however, unlikely that the differences between the sexes arise from this source. Both the analyses of variance and the $\mathrm{Wr} / \mathrm{Vr}$ and $\mathrm{W}^{\prime} \mathrm{r} / \mathrm{Wr}$ analyses strongly indicate that the majority of the variation between the samples arises from the action of the sex chromosomes.

Further information on the activity of the sex chromosomes was obtained from the examination of the sex difference. The mean difference between the sexes varies considerably from group to group, and the analysis of variance (table 3 ) shows that some of the variation is significant. In addition there is a two and a half fold difference

$$
\text { Flowering Time } \quad \text { to- } \delta \delta
$$

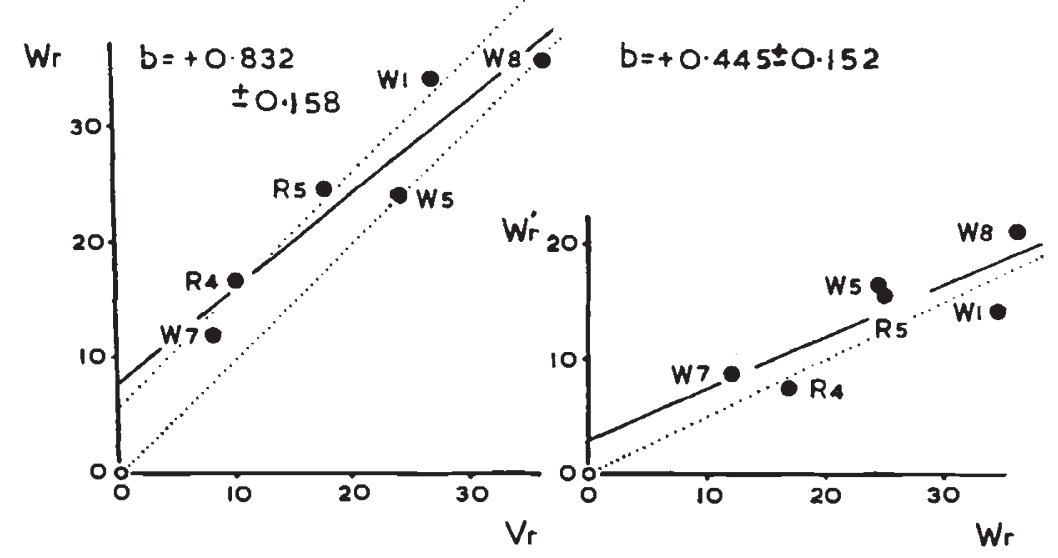

FIG. 2.- $\mathrm{Wr} / \mathrm{Vr}$ and $\mathrm{Wr} / \mathrm{Wr}$ graphs for the sex difference in flowering time. Broken lines as in fig. 1 .

between the mean variance within parent, as compared to $F_{1}$, groups (table 3, items 2 (i) and (ii)). The parent and $F_{1}$ variances are homogeneous among themselves (Heterogeneity of parent variances $\mathrm{P}=0.5^{-}$ 0.3 , of $F_{1}$ variances $\left.P=0 \cdot 7-0.5\right)$. In so far as this variation is genetic, the presence of dominance is indicated (Mather, I943, I96o; Breese and Mather, I960). It was argued previously (Lawrence, I963) that smaller variation within $F_{1}$ groups also probably arises from the action of some form of epistasis.

Both the $\mathrm{Wr} / \mathrm{Vr}$ and the $\mathrm{W}^{\prime} \mathrm{r} / \mathrm{Wr}$ regression for the sex difference (fig. 2) is significant ( $\mathrm{P}=0.0 \mathrm{I}-0.00 \mathrm{I}$ and $\mathrm{P}=0.05^{-0} .0 \mathrm{I}$ respectively). The distribution of the six points on two parallel lines of unit slope in the $\mathrm{Wr} / \mathrm{Vr}$ graph suggests that the samples differ with respect to heterozygosity. The positive intercept of the $\mathrm{Wr} / \mathrm{Vr}$ regression on the $\mathrm{Wr}$ axis appears to arise from these differences in heterozygosity, and not from incomplete dominance (cf. Lawrence, I 963). The order of dominance differs from that in either the male or female progeny. 


\section{(ii) Plant weight}

The average weights of the groups of male and female plants are given in table 4. The results of the analyses of variance (table 5) show that, as with flowering time, there is considerably more variation between, than within, groups in both sexes. In contrast to the flowering time data, however, the distribution of variation is very similar in males and females. In both there is significant variation

TABLE 4

The avereage plant weight of each parent and $F_{1}$ group

\begin{tabular}{|c|c|c|c|c|c|c|}
\hline & $W_{I}$ & $\mathrm{~W}_{5}$ & $w_{7}$ & W8 & $\mathrm{R}_{4}$ & $\mathrm{R}_{5}$ \\
\hline$W_{I}$ & $\begin{array}{r}10.2 \\
8.7\end{array}$ & $\begin{array}{r}12.6 \\
8.2\end{array}$ & $\begin{array}{r}9.9 \\
10.9\end{array}$ & $\begin{array}{r}10.8 \\
7.9\end{array}$ & $\begin{array}{r}17.5 \\
15.7\end{array}$ & $\begin{array}{r}14.3 \\
13.4\end{array}$ \\
\hline$W_{5}$ & $\begin{array}{l}15.6 \\
10.9\end{array}$ & $\begin{array}{l}14.9 \\
13.8\end{array}$ & $\begin{array}{l}18.4 \\
14.9\end{array}$ & $\begin{array}{l}14.0 \\
14.5\end{array}$ & $\begin{array}{l}21 \cdot 4 \\
21 \cdot 5\end{array}$ & $\begin{array}{l}17 \cdot 6 \\
16.7\end{array}$ \\
\hline$w_{7}$ & $\begin{array}{l}15.2 \\
13.9\end{array}$ & $\begin{array}{l}16 \cdot 3 \\
11 \cdot 6\end{array}$ & $\begin{array}{l}14 \cdot 8 \\
12 \cdot 1\end{array}$ & $\begin{array}{l}14.7 \\
10.6\end{array}$ & $\begin{array}{l}15.3 \\
13.6\end{array}$ & $\begin{array}{l}16 \cdot 2 \\
17 \cdot 2\end{array}$ \\
\hline W8 & $\begin{array}{l}13.4 \\
11.0\end{array}$ & $\begin{array}{l}15.3 \\
13.8\end{array}$ & $\begin{array}{r}10.5 \\
9.1\end{array}$ & $\begin{array}{r}10.8 \\
8.7\end{array}$ & $\begin{array}{r}17.5 \\
14.0\end{array}$ & $\begin{array}{l}16.5 \\
15.5\end{array}$ \\
\hline $\mathrm{R}_{4}$ & $\begin{array}{l}\text { I4.0 } \\
10.5\end{array}$ & $\begin{array}{l}16.3 \\
10.7\end{array}$ & $\begin{array}{l}20 \cdot 8 \\
12 \cdot 1\end{array}$ & $\begin{array}{r}12 \cdot 8 \\
8 \cdot I\end{array}$ & $\begin{array}{l}17.6 \\
12.2\end{array}$ & $\begin{array}{l}12.3 \\
17 \cdot 1\end{array}$ \\
\hline $\mathrm{R}_{5}$ & $\begin{array}{r}14.9 \\
11.8\end{array}$ & $\begin{array}{l}19.3 \\
14.9\end{array}$ & $\begin{array}{l}18.8 \\
16.0\end{array}$ & $\begin{array}{l}18.3 \\
13.7\end{array}$ & $\begin{array}{l}20 \cdot 7 \\
21 \cdot 2\end{array}$ & $\begin{array}{r}17.0 \\
16.4\end{array}$ \\
\hline
\end{tabular}

Top figure $=$ female plants. $\quad$ Bottom figure $=\mathrm{n} \cdot \quad \ldots \ldots \omega$.

among parents, $F_{1}$ 's and also a consistent deviation of the $F_{1}$ 's from the mid parent (table 5, items I (i), (ii) and (iii)). Additive and dominance variation between the samples is therefore found in both sexes. Unexpectedly there are significant differences between reciprocal $F_{1}$ groups in female, but not male, progeny (item I (iv)). Despite this, it appears that the majority of the variation in weight in the samples is autosomal in origin.

$\mathrm{Wr} / \mathrm{Vr}$ and $\mathrm{W}^{\prime} \mathrm{r} / \mathrm{Wr}$ regressions (fig. 3) are highly significant in both sexes (males $\mathrm{Wr} / \mathrm{Vr}$ and $\mathrm{W}^{\prime} \mathrm{r} / \mathrm{Wr} \mathrm{P}=0 \cdot 0 \mathrm{I}-0 \cdot 00 \mathrm{I}$, females $\mathrm{Wr} / \mathrm{Vr}$ and $\mathrm{W}^{\prime} \mathrm{r} / \mathrm{Vr}$ and $\left.\mathrm{W}^{\prime} \mathrm{r} / \mathrm{Wr} \mathrm{P}<\mathrm{o} \cdot \mathrm{OoI}\right)$, showing the high heritability of plant weight. The slopes of the regressions are all close to the expected values. There is no evidence of different levels of heterozygosity among the various samples in the female data, but the scatter 


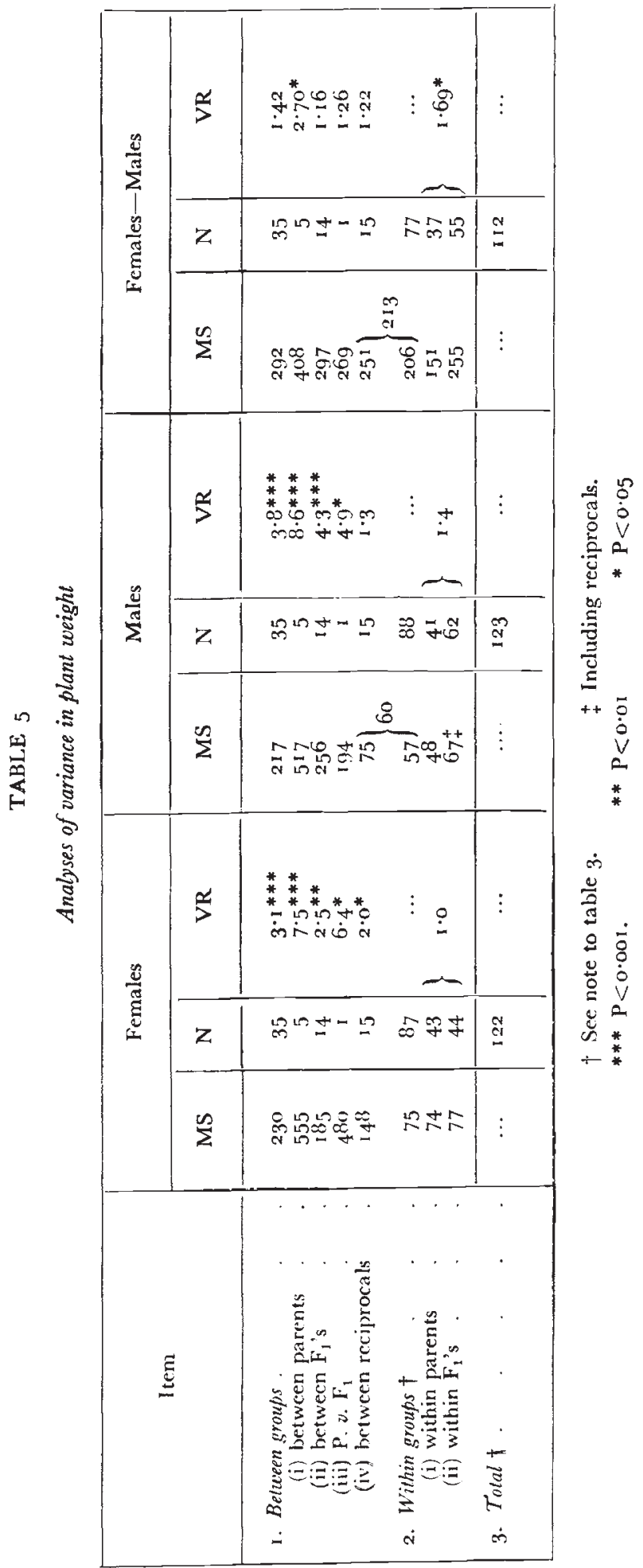


of the points about the male $\mathrm{Wr} / \mathrm{Vr}$ regression may arise from this cause.

Despite the lack of significant variation between reciprocal $F_{1}$ male progeny, the dominance ranking in the two sexes differs to a certain extent, suggesting sex chromosome activity. The results of the analysis of variance (table 5) of the sex difference in plant weight

\section{Plant Weight $\sigma^{\circ} \sigma^{\circ}$}

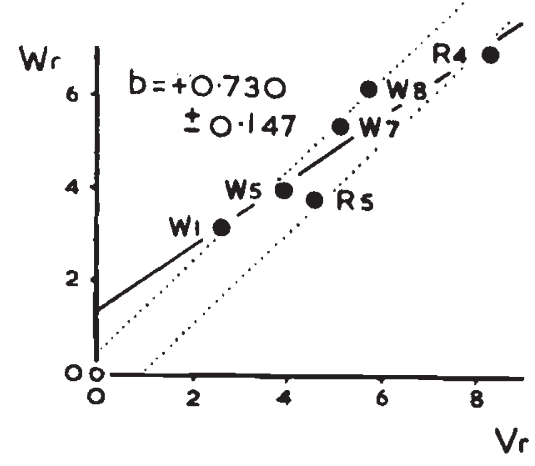

$b=+0.596 \pm 0.116$

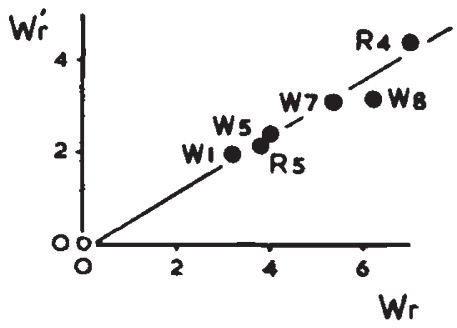

우

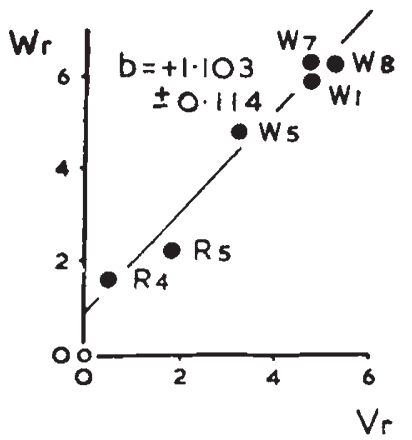

$b=+0.492 \pm 0.021$

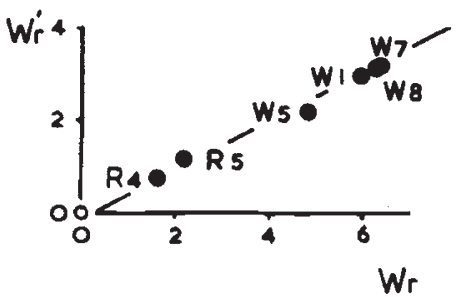

Frg. 3. $-\mathrm{Wr} / \mathrm{Vr}$ and $\mathrm{W}^{\prime} \mathrm{r} / \mathrm{Wr}$ graphs for male, and female weight. Broken lines as in fig. I.

support this conclusion. There is significant variation among the parents (table 5, item I (i)), and also significantly greater variation on the average within $F_{1}$ than within parent groups. The different $\mathrm{F}_{1}$ and parent variances are homogeneous among themselves (heterogeneity of parent variances $P=0.5-0 \cdot 3$, of $F_{1}$ variances $\left.P=0 \cdot 7-0.5\right)$. This indicates the presence of dominance (Mather, 1943, I960; Breese and Mather, 1960). Despite such evidence, it is clear that the variation between groups is not great. It is probably for this reason 
that variation between reciprocal $F_{1}$ male progeny was not detected. The insignificance of the $\mathrm{Wr} / \mathrm{Vr}$ and the $\mathrm{W}^{\prime} \mathrm{r} / \mathrm{Wr}$ regressions (fig. 4) also agrees with this conclusion.

Plant Weight
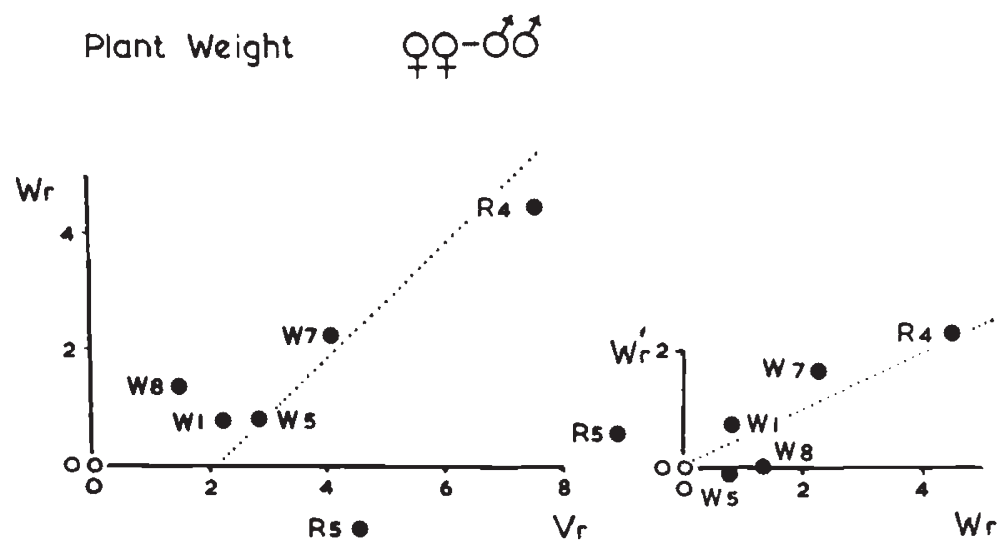

FIG. 4. - Wr/Vr and $\mathrm{W}^{\prime} \mathrm{r} / \mathrm{Wr}$ graphs for the sex difference in weight. Broken lines as in fig. 1 .

(iii) Variance within and between intra-population families

The ratio of the variance of family means to the mean variance within intra-population families for each character is given in table 6 .

TABLE 6

Rates of the variance between families to the average variance within them

\begin{tabular}{|c|c|c|c|c|c|c|}
\hline \multirow{2}{*}{ 莺 } & \multirow{2}{*}{$\begin{array}{l}\text { Chiasma } \\
\text { frequency }\end{array}$} & \multirow{2}{*}{$\begin{array}{c}\text { Cell } † \\
\text { variance }\end{array}$} & \multicolumn{2}{|c|}{ Flowering time } & \multicolumn{2}{|c|}{ Plant weight } \\
\hline & & & 우 & రే & $q$ & 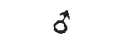 \\
\hline $\begin{array}{l}W_{1} \\
W_{5} \\
W_{7} \\
W_{8} \\
\mathrm{R}_{4} \\
\mathrm{R}_{5}\end{array}$ & $\begin{array}{c}\ldots \\
\ldots \\
2 \cdot 66^{*} \\
2 \cdot 6^{*} \\
0 \cdot 69 \\
1 \cdot 99\end{array}$ & $\begin{array}{c}\ldots \\
\ldots \\
1 \cdot 93 \\
1 \cdot 24 \\
0 \cdot 62 \\
1 \cdot 13\end{array}$ & $\begin{array}{l}4 \cdot 95^{* * *} \\
3 \cdot 90^{* * *} \\
1 \cdot 94 \\
2 \cdot 78^{* *} \\
2 \cdot 92^{*} \\
2 \cdot 62^{*}\end{array}$ & $\begin{array}{l}I \cdot 60 \\
1 \cdot 01 \\
2 \cdot 60^{*} \\
3 \cdot 92^{* * *} \\
0 \cdot 65 \\
7 \cdot 62^{*}\end{array}$ & $\begin{array}{l}5 \cdot 11 * * \\
2 \cdot 09 \\
0 \cdot 98 \\
\text { I. } 84 \\
\text { I. } 49 \\
2 \cdot 44^{*}\end{array}$ & $\begin{array}{l}7.35^{* * *} \\
5.74^{*} \\
1.12 \\
0.99 \\
1 \cdot 13 \\
3.81 * *\end{array}$ \\
\hline
\end{tabular}

$\dagger$ Taken from Lawrence 1963 .

In twenty-seven of the thirty-two cases the variation between families is the greater, and is significantly so in fifteen cases.

(iv) Sex ratio

The average proportion of females varies considerably from group to group (table 7). In most, but not all, cases there is a significant excess of females over males. An analysis of variance, of the 
TABLE 7

Per cent. females in the parent and $F_{1}$ groups

\begin{tabular}{|c|c|c|c|c|c|c|}
\hline$\delta^{*}$ & $\mathrm{~W}_{\mathrm{I}}$ & $\mathrm{W}_{5}$ & $\mathrm{~W}_{7}$ & $\mathrm{~W} 8$ & $\mathrm{R}_{4}$ & $\mathrm{R}_{5}$ \\
\hline $\mathrm{W}_{\mathrm{I}}$ & $4^{\mathrm{I}}$ & $8 \mathrm{I}$ & 62 & 48 & 77 & $6 \mathrm{I}$ \\
\hline $\mathrm{W}_{5}$ & 60 & 83 & 68 & 52 & 85 & 60 \\
\hline $\mathrm{W}_{7}$ & $4^{\mathrm{I}}$ & 79 & $5 \mathrm{I}$ & 68 & 60 & 62 \\
\hline $\mathrm{W}_{8}$ & $3^{6}$ & 56 & $4^{2}$ & 54 & $5 \mathrm{I}$ & $6 \mathrm{I}$ \\
\hline $\mathrm{R}_{4}$ & 24 & 66 & $3^{6}$ & 50 & 68 & $4^{8}$ \\
\hline $\mathrm{R}_{5}$ & 47 & 73 & 53 & $2 \mathrm{I}$ & $6 \mathrm{I}$ & 54 \\
\hline
\end{tabular}

TABLE 8

Analysis of variance in sex ratios (per cent. females transformed to angles)

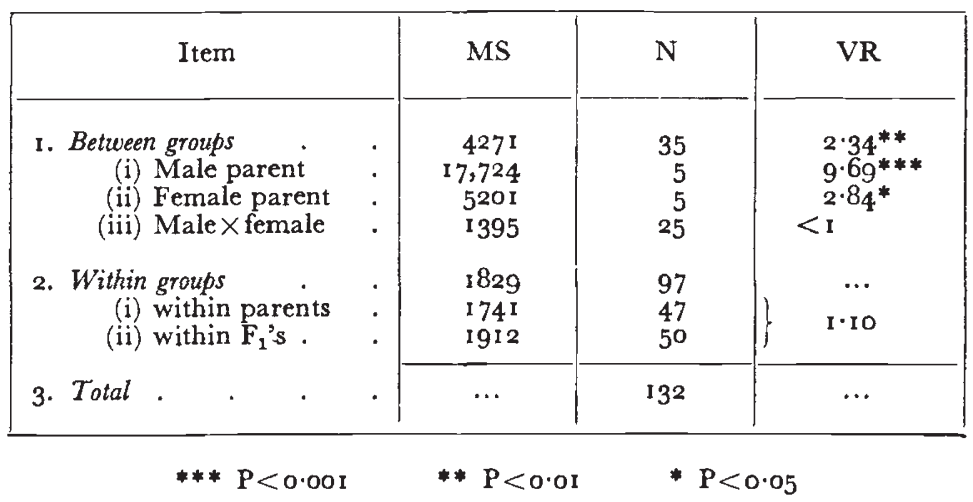

percentage females converted to angles (Fisher and Yates, 1957), shows that the differences between the crosses are significant (table 8). Further the majority of the variation is attributable to the male parent. However, a small, significant, influence of the female parent is also found.

\section{DISCUSSION}

It has been shown that with regard to both flowering time and plant weight greater genetic variation existed between the population samples than within them. The two characters exhibited both additive and dominance variation between the samples, but differed in the 
distribution of activity among the chromosomes. The variation in flowering time arose largely, possibly exclusively, from the activity of the sex chromosomes. Of these, only the $\mathrm{X}$ chromosome appears to have activity. No evidence was found to indicate a direct effect of the Y chromosome. An indirect effect, although unlikely, cannot, however, be entirely excluded. The dominance variation among male progeny, indicated by the significant $\mathrm{W}^{\prime} \mathrm{r} / \mathrm{Wr}$ regression, may be autosomal in origin, or arise from the pairing segment of the sex chromosomes. It appeared to be of relatively minor importance as it was not detected by an analysis of variance. In contrast to flowering time, the variation in plant weight was largely autosomal with only a small effect of the sex chromosomes.

Apart from the different gene frequencies in the samples, differences in the level of heterozygosity with regard to flowering time and possibly also weight are suggested by the $\mathrm{Wr} / \mathrm{Vr}$ analyses. The differences are shown by the distribution of points on parallel lines of unit slope in the $\mathrm{Wr} / \mathrm{Vr}$ graphs. These parallel lines have been fitted by eye, and no attempt has been made to test the fit statistically. However, the distribution of points bears a striking resemblance to that expected theoretically (Dickinson and Jinks, I956).

Insofar as the samples are adequate and representative, the conclusions reached concerning the nature of the differences between the samples can be extended to the populations from which they were drawn. Extrapolation becomes more reliable the greater the number of genes by which the samples differ in each gene system. It is clear from the results that there are at least several, and most probably many, genes influencing either flowering time or weight in these plants.

The marked effect of the sex chromosomes on flowering time and negligible activity of the autosomes points to the adaptive importance of particular relations between males and females. Analysis of the sex difference demonstrated that the various groups of crosses did in fact possess characteristic relations between the sexes. In general males flowered earlier than females, but the average sex difference varied widely. At one extreme, in the $\mathrm{W}_{5}$ group of intra-population crosses, males flowered an average of nearly seventeen days earlier than the females. At the other extreme, the males in the $R_{4}$ and $\mathrm{R}_{5}$ intra-population families flowered at the same time as the females, or even, perhaps, a little later. $\mathrm{Wr} / \mathrm{Vr}$ and $\mathrm{W}^{\prime} \mathrm{r} / \mathrm{Wr}$ analysis suggests that the sex difference is controlled by a polygenic system exhibiting ambidirectional dominance and heterozygosity. In the production of the sex difference the action of the sex chromosomes can be of two principal kinds. First, direct action; that is the difference between the average effect of a pair of chromosomes and the average effect of a single chromosome. This presumably depends largely on dominance, although other interactions may also occur. Second, indirect action or sex limitation (Morgan, I9I4), where there is an 
interaction between the gene system controlling flowering time and that determining sex. The first alternative, that of direct action, does not appear likely in the present material. If the sex difference depended on dominance, it would be expected that on the average the size of the difference would be greater in the inter-population than in the intra-population hybrids. This is not found. Further, if the autosomes and the $\mathrm{Y}$ chromosome can be neglected, as is suggested by the data, it should be possible to predict the relative sizes of the sex difference in the inter-population hybrids from the $\mathrm{Wr} / \mathrm{Vr}$ graph of the females since this gives the dominance relation of the $\mathrm{X}$ chromosomes. This does not, however, prove to be possible. On the other hand no positive predictions can be made to test the hypothesis of sex limitation. A factor complicating the attempt to distinguish between the two alternatives is shown by the significant differences between the groups of reciprocal families with respect to female weight. These probably arise from maternal or cytoplasmic inheritance.

The sparse evidence for genetic variation in flowering time of male plants from different populations, even though such variation is found in female plants, may be due to gene-environment interaction which has been shown to be an important factor in the flowering of populations of grasses (Cooper, 1955). The early flowering of males relative to females presumably ensures that an adequate supply of pollen is available when the stigmata are receptive. The variation in the extent of this earliness may arise from variation in the conditions of pollination.

The six groups of intra-population families are closely similar to the biparental progenies of Mather (1949). If the parents of such groups of families have been drawn from randomly mating populations, the mean genetic variation within families is expected to be larger than, or at least equal to, that between family means (Mather, I949 ; Hayman and Mather, I955). The reverse was found, which indicated that a certain amount of inbreeding took place in the parent population. The variances compared in table 6 contained components due to environmental or error variance, and thus the comparisons are not entirely valid. However, the environmental variance associated with the observations within families will be greater than that for family means, and thus the ratios of true genetic variance will be larger than those given in table 6 .

Departures from equality in the numbers of males and females, generally giving an excess of the homogametic sex, have been reported for a number of plant species possessing $\mathrm{XY}$ sex chromosome mechanisms (Lewis, 1942). In Melandrium, Correns (1928) showed that this departure resulted from gametic rather than zygotic selection. $\mathrm{X}$ bearing pollen grew faster down the style than $\mathrm{Y}$ bearing pollen, giving an excess of female plants when there was pollen competition. The differential growth rates of $\mathrm{X}$ and $\mathrm{Y}$ pollen was shown to be controlled by the genotype of the male parent (Correns loc. cit.). In 
the present experiment, all pollinations were carried out with excess pollen, and thus maximum departures from a one to one ratio will have been obtained. The results demonstrate the importance of the male parent in determining the sex ratio, and further show that therc are genetic differences between populations with regard to this character. The small effect of the female parent shown by the results may arise from an influence of the style on the differential growth rates of $\mathrm{X}$ and $\mathrm{Y}$ pollen, or possibly from zygotic selection.

Different sex ratios in the various populations may reflect the different efficiencies of pollinating agents in different environments. This in turn could be related to the density of plants or the predominant pollinating insect species. Alternatively different sex ratios may be concerned with recombination, since recombination is often higher in the homogametic sex (Haldane, I922).

\section{SUMMARY}

Greater genetic variation has been found between samples from four wild populations of Melandrium album and two of $M$. rubrum than within them, for flowering time and plant weight. Both characters show additive and dominance variation, and the populations also probably differ in the level of heterozygosity in the two gene systems. Weight was found largely to be an autosomal character, while flowering time was determined almost entirely by the sex chromosomes in these plants. The characteristic differences in flowering time of male and female plants in the various populations appeared to result from an indirect action of the $\mathrm{X}$ chromosomes, that is by sex limitation, rather than from a direct action The populations have different sex ratios and inbreed to a certain extent.

Acknowledgments.-I am greatly indebted to Prof. K. Mather, F.R.S. and to Dr H. Rees for advice and criticism throughout the course of this work. I would also like to thank Dr J. L. Jinks for much useful discussion.

\section{REFERENCES}

BREESE, E. L., AND MATHER, K. 1960. The organisation of polygenic activity within a chromosome of Drosophila. II. Viability. Heredity, 14, 375-399.

COOPER, J. P. I959. Selection and population structure in Lolium. I. The initial populations. Heredity, 13, 317-340.

CORRENS, c. 1928. Bestimmung, Vererbung and Verteilung des Geschlectes bei den hoheren Pflanzen. Handb. der Vererbungsw. IIc. I-138, Berlin.

Dickinson, A. G., AND JINKs, J. L. I956. A generalised analysis of diallel crosses. Genetics, 4I, 65-78.

Fisher, R. A., AND yates, F. 1957. Statistical Tables for Biological, Agricultural and Medical Research. 5th ed. Oliver and Boyd.

hALDANE, J. B. S. 1922. Sex ratio and unisexual sterility in hybrid animals. $\mathcal{f}$. Genetics, 12, I0I-109.

hayman, B. I. 1958. The theory and analysis of diallel crosses II. Genetics, 43, $63-85$. 
HAYMAN, B. I., AND MATHER, K. 1955. The description of genic interactions in continuous variation. Biometrics, $11,69-82$.

JiNks, J. L. I954. The analysis of continuous variation in a diallel cross of Nicotiana rustica varieties. Genetics, 39, 767-788.

I.AWRENCE, C. W. 1963. Genetic studies on wild populations of Melandrium. I. Chromosome behaviour. Heredity, 18,135 - 148 .

LEWIS, D. 1942. The evolution of sex in flowering plants. Biol. Rev., 17, 46-67.

mather, K. 1943. Polygenic inheritance and natural selection. Biol. Rev., 18, $32-64$.

MATHER, K. 1949. Biometrical Genetics. Methuen.

MATHER, K. 1960. Evolution of polygenic systems. Evoluzion e Genetica, 47, 131-152.

Morgan, T. H. I914. Heredity and Sex. New York. 